\title{
Learning Service Satisfaction of Master Degree Graduates of Vocational Education in State University of Malang
}

\author{
$1^{\text {st }}$ Muhammad Rahmatullah \\ Vocational Education Study Program \\ Universitas Negeri Malang \\ Malang, Indonesia \\ matt.cyberjack@gmail.com
}

\author{
$2^{\text {nd }}$ Amat Mukhadis \\ Vocational Education Study Program \\ Universitas Negeri Malang \\ Malang, Indonesia \\ mukhadis.ft@um.ac.ic
}

\author{
$3^{\text {rd }}$ Ap if Miptahul Hajji \\ Vocational Education Study Program \\ Universitas Negeri Malang \\ Malang, Indonesia \\ apif.miptahul.ft@um.ac.id
}

\begin{abstract}
This study aims to reveal and describe the relationship between the learning process conducted at graduate program of vocational education (PKJ) at State University of Malang (UM) and what is faced by the graduates in work field. This is a tracer study with qualitative descriptive approach. The research subjects cover all magister graduates of PKJ UM 2007 2012 living in Malang and its surrounding. The research objects cover: graduates' satisfaction on the learning quality, and their profiles in the work fields. The data are collected through documentation, questionnaires, interview guide, and recording device. The data is analyzed statistically-descriptively. The findings of the study show that the graduates overall feel satisfied with the learning process they are taking at the Graduate Program of S2 PKJ UM, viewed from tangibility, reliability, responsiveness, assurance, and empathy aspects; they also get hired easily, adapt well in the work fields, and have promising position, viewed from their main job after the graduation, their main job salary, their methods to get job, and how long they waited for the job.
\end{abstract}

Keywords-learning service satisfaction; adaptation ability; tracer study.

\section{INTRODUCTION}

The National Education System in Indonesia aims to educate the life of the nation and develop a complete Indonesian man so they can grow with creative, innovative, and future-oriented attitudes and behaviors [9]. The National Education System today serves to develop the ability and improve the quality of life and human dignity of Indonesian in order to realize the national goals [41]. The National Education System is divided into educational units, education path, type of education, and education level. Vocational education is one type of education in the National Education System, which primarily aims to prepare learners to be able to work in a certain field and also ready to move on to higher education level. To face the economic and industrial competition, graduates of vocational education are charged with a high expectation. They are required to have pedagogical, personality, social, and professional competence[38]. They are required to be able to read the situation of the learning world, make decisions relating to the learning problems, and reflect on the learning which has been going on [39]. More specifically, National Education of Ministerial regulation No.22 (2006) describes the purpose of vocational education as follows.

The specific purpose of vocational education is to improve the intelligence, knowledge, personality, noble character, and skills of learners to live independently and follow a further education in accordance with his vocational program in order to work effectively and efficiently, develop their expertises and skills, master the skills and the basics of science and technology, have a high work ethic, communicate according to job demands, and have the ability to develop themselves.

So it can be argued that technological and vocational education is an education held for students who plan and develop their careers in a particular area of expertise to work productively and professionally and also ready to move on to the higher levels of education.

In the implementation of education all this time, however, vocational education is still considered to fail to achieve the design of the established goals [9]. Graduates' students of vocational college still need training on the technology being used in the industry, when entering into the work's world. Many of university graduates in Indonesia are unacceptable in the work's world because of the wide gap between the qualifications of college graduates in Indonesia with the qualifications of the workforce required by the work's world [19].

Suryadi added, it is also due to the imbalance between workforce supply structures with the employment's structure according to the education [44]. The governments realize that there is a very basic problem in vocational education that must be fixed where the condition occurs because of the inconsistency of education implementation caused by several factors [46]. One of them is because of human resources as educational provider is not professional according to its field [9]. Mukhadis states that the dialectical demands of the era of knowledge and technology used as a reference in human resources (HR) who has the advantage of competence and 
character in the field of technology [23]. In order to prepare qualified human resources, the improving of the quality of educational services become the government's main program now [14]. HR in the future is expected to be more resilient, independent, responsible, diligent, disciplined, honest and broad-minded and able to identify, seek and utilize information in order to have variations of excellence in their respective fields [23]. Referring to this, the human resources as an educational provider who has high competence and work professionally according to their field is needed. This will give a lot of positive influence on national development especially on the decreasing unemployment rate in Indonesia and the increasing of economy [33]. Such human resources need to be prepared in the higher education.

Currently, vocational education in Indonesia is also known still face various problems [44]. Rahmatullah presents some of the issues of vocational education today, such as low quality and professionalis $m$ in the evaluation of vocational education that is not oriented to the needs of the market, lack of community and business support towards the development of vocational education, and lack of supporting facilities and infrastructure [33]. From some of these opinions, the researchers assume that the relationship between vocational higher education as a forum of learning process with the graduates who have entered the work field need to be examined. Evaluation needs to be done as a means to determine the relevance. The components which determine the success of a learning process is an evaluation [16]. In Indonesia, academic efforts related to the relationship of higher education with the world of work have not so much gained attention, but it is needed by every college to know the success of the educational process that has been done to their students [22]. Increased competition among universities at the national and international levels requires the provision of education based on a good quality management system to produce good character graduates, have a high competence, and profes sional in work [2]. Because of from qualified teachers and qualified institutions, qualified human resources can be obtained [48].

In this case, a tracer study is required. Tracer study is a graduate trace study that is generally conducted 1-3 years which is useful to measure and track the performance of graduates so that can be obtained a clear indicator about the profile of graduates [37]. Further, Schomburg adds, tracer study is a study of graduates of institutions of higher education [40]. Tracer study is conducted to measure the performance of the study program through the output produced by the study program in forming graduates that can meet the demands of the era [49]. Information from the tracer study is indispensable for development purposes and as one of the foundations for future academic policy in order to establish the implementation of quality assurance system of education in accordance with the demands of the needs and dynamics of society [10]. In addition, the most important is the acquisition of information or input from the graduates about the conditions of competition in the field of work so it can be used to improve the curriculum so the quality of graduates can be better [28]. Thus, through the tracer study, researcher trying to examine the relationship between learning that organized by the Magister Program of Vocational
Education in State University of Malang with the work's world faced by the graduates.

Master degree program of Vocational Education State University of Malang (PKJ UM) is one of the departments from master degree department in postgraduate of Malang University that has harmonious expectation with the selected purpose of vocational education, that is to prepare educators potential as an international standard teacher and/or manager and other practitioners in the world of vocational education, so it has the ability to solve problems and to increase the quality of vocational education. This is also clearly illustrated in the vision, mission, and objectives. Several components in the curriculum form characteristics of master degree graduates of PKJ UM through several competences which are developed in it. hopefully, the master degree graduates of PKJ UM finally become organizers of vocational education whose high competence and professionalism based on his ability.

The observed aspects of the relationship have contexts on satisfaction of learning service that has been taken by the master degree graduates in PKJ UM, as well as the profile of graduates in employment [45]. The observe graduates are categorized by the researcher into three categories, they are: graduates who work in Higher Education, vocational high school and other institutions. Hence, the description of the correlation between the master degree of PKJ UM's expectation and the reality of graduates in employment for the need to improve the quality of learning.

\section{METHOD}

The study design uses quantitative descriptive design which is aimed to give phenomenon [26], which examines the phenomenon, mencandra, mapping, classifying phenomena examined at specific time intervals [26]. Quantitative descriptive design is more concerned with the effort to uncover and describe a variable without relating it to other variables, which is in accordance with the scope of descriptive research that does not intend to test a research hypothesis [26].

The subject of this research is all of master degree graduates of PKJ UM academic year 2007-2012 with 127 graduates population. The samples are taken by purposive sampling technique where the graduates residing in Malang and its surroundings are assigned as research samples, and the sample number is 50 graduates. Purposive sampling is used when the researcher has certain considerations and is tailored to the objectives of the study, as well as the aspect of the sample size which is not a major consideration [26]. This subject is chosen because it is considered to be capable of providing the required data by considering the time efficiency, effort, and possible research reach [42]. Research subjects are divided into three categories, they are: graduates who work in Universities, Vocational High School, and other Institutions. The object of this research is the satisfaction of learning service, as well as the profile of master degree graduates of PKJ UM in the workplace.

The study uses a tracer study. The data are collected with documentation, questionnaires, interview guides, and tape recorders [7]. The instrument uses non test questionnaire 
instrument, which is intended to perform data collection that is not individual capability, but the tendency of individual characteristics of a phenomenon presented as a stimulus [26]. The form questionnaire is 'rank scale' (ranking scales). The measurement scale uses Likert Scale in the form of checklist[26], which is meant to measure attitudes, opinions, and perceptions of a person or a group of social phenomena[42]. The interview guide is not much different from the content of the questionnaire. The interview uses unstructured interview form [27], which is assumed to complete the data from the questionnaire. Meanwhile, the recording device uses mobile phone recording applications, which can be used in telephone interviews or direct interviews. In the instrument, its validity and reliability are tested as an instrument quality indicator [25], using IBM SPSS Statistics version 20 via descriptive analysis.

Data analysis technique uses descriptive statistical technique through the application of IBM SPSS Statistics version 20 which aims to describe, map or mencandra a phenomenon which is the object of the study [27]. The criteria for determining the intervals of each category is calculated using the ideal rate as the benchmark to determine the category. Through the results of interval scale scores it can be made an interval class to determine the category of perception of the research response [4]. The analys is of each question / statement on the instrument is then formulated by category percentage, then consulted with interpretation guidelines [4].

\section{RESULT}

\section{A. Profile of Master Degree Graduates of Vocational Education State University of Malang}

Graduate profiles are revealed and described through the graduate's primary activities after graduation, monthly income of the primary job, job search methods, and waiting periods. The identity of the graduate is described by respondent's domicile, respondent's gender, place of respondent's work, and comparison of domicile and sex according to place of respondent's work. Then it is known that respondents who are domiciled in Malang amounted to 41 people (82\%) and respondents who are domiciled in the area around Malang amounted to 9 people (18\%). Furthermore, the gender of the respondents consists of 33 males $(66 \%)$ and 17 females $(34 \%)$. The respondent's workplace is disclosed in accordance with the research design, namely: respondents working in universities amounted to 31 people $(62 \%)$, respondents working in vocational school amounted to 10 people (20\%), and respondents working in otherinstitutions amounted to 9 people $(18 \%)$.

Comparison of domicile and gender of respondent in terms of respondent's workplace can now be described as follows. First, respondents working in universities consist of 26 people living in Malang (84\%) and 5 people are domiciled around Malang (16\%) with male respondents as many as 19 people $(61 \%)$ and female respondents as many as 12 people $(39 \%)$ Secondly, the respondents working in vocational schoolconsist of 6 people living in Malang $(60 \%)$ and 4 people are domiciled around Malang (40\%) with male and female respondents of 5 people each. Third, respondents working in other institutions, all of them are domiciled in Malang and all of them are male respondents. The comparison diagram can be seen in the following picture.

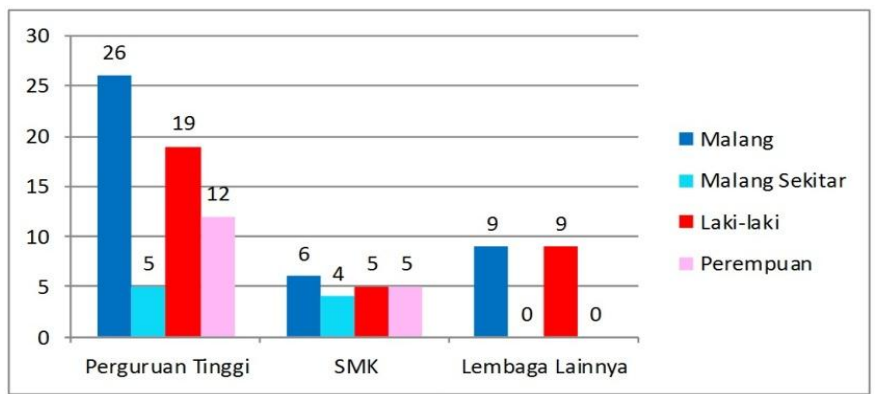

Fig. 1 Diagram of comparison of domicile and sex according to place of work of respondent

Furthermore, graduate profiles related to graduate activities after graduation, monthly employment income, job search methods, and waiting periods are described below. First, the main activity that most graduates choose after graduation is permanent work, whether it is graduates who work in Universities, Vocational Schools, as well as Other Institutions. This can be seen in the following table.

TABLE I GRADUATES'ACTIVITIES AFTER GRADUATION

\begin{tabular}{|l|l|l|l|}
\hline \multirow{2}{*}{ Category } & \multicolumn{3}{|c|}{ Number / Percentage by Workplace Graduates } \\
\cline { 2 - 4 } & Higher education & Vocational school & $\begin{array}{l}\text { Other } \\
\text { institutions }\end{array}$ \\
\hline Work remains & 27 persons (87\%) & 10 persons (100\%) & $\begin{array}{l}9 \text { persons } \\
(100 \%)\end{array}$ \\
\hline $\begin{array}{l}\text { Work is not } \\
\text { fixed/odd }\end{array}$ & 3 persons (10\%) & - & - \\
\hline $\begin{array}{l}\text { Married/busy } \\
\text { with family }\end{array}$ & 2 persons (6\%) & - & - \\
\hline $\begin{array}{l}\text { Continue } \\
\text { study }\end{array}$ & 3 persons (10\%) & 1 person (10\%) & - \\
\hline Taking course & - & - & - \\
\hline Jobless & - & - & - \\
\hline $\begin{array}{l}\text { Others } \\
\text { (organize, self- } \\
\text { employed, etc.) }\end{array}$ & 1 person (3\%) & 4 persons (40\%) & - \\
\hline
\end{tabular}

(Source: Descriptive analysis results with Microsoft Excel 2010)

Table 1 shows that: (1) graduates working in universities are generally in the category of permanent employment, and a small proportion in categories: non-permanent employment, married / busy with family, continuing studies, and others (organizing, self-employment, etc. ); (2) graduates who work in vocational school all in the category of permanent employment, almost half of them in the category Others (organize, entrepreneurship, etc.), and a small part in the category continue to study; and (3) graduates working in Other Institutions are entirely in the category of permanent employment.

Secondly, the monthly income of most graduates is $2.5-5$ million for graduates working in Universities and vocational schools, and 7.5 to 10 million for graduates working in Other Institutions. This can be seen in the following table. 
T ABLE II MONTHLY INCOME OF GRADUATES

\begin{tabular}{|l|l|l|l|}
\hline \multirow{2}{*}{ Category } & \multicolumn{3}{|c|}{ Number / Percentage based on Workplace } \\
\cline { 2 - 4 } & Higher education & $\begin{array}{c}\text { Vocational } \\
\text { School }\end{array}$ & $\begin{array}{c}\text { Other } \\
\text { institutions }\end{array}$ \\
\hline$<1$ million & 2 persons $(6 \%)$ & 1 person $(10 \%)$ & - \\
\hline $1-2,5$ million & 7 persons $(23 \%)$ & 3 persons (30\%) & - \\
\hline $2,5-5$ million & 13 persons $(42 \%)$ & 4 persons $(40 \%)$ & $\begin{array}{l}2 \text { persons } \\
(22 \%)\end{array}$ \\
\hline $5-7,5$ million & 5 persons $(16 \%)$ & 2 persons $(20 \%)$ & $\begin{array}{l}2 \text { persons } \\
(22 \%)\end{array}$ \\
\hline $7,5-10$ million & 4 persons $(13 \%)$ & - & $\begin{array}{l}4 \text { persons } \\
(44 \%)\end{array}$ \\
\hline$>10$ million & - & - & $\begin{array}{l}1 \text { person } \\
(11 \%)\end{array}$ \\
\hline \multicolumn{2}{|r|}{ (Source: Descriptive analysis results with Microsoft Excel 2010) }
\end{tabular}

Table 2 shows that: (1) graduates working in universities are almost half in the 2.5 to 5 million category, and a small percentage in the category: <1 million; 1 - 2.5 million; 5 - 7.5 million; and 7.5 - 10 million; (2) graduates who work in SMK almost half of the category $1-2.5$ million and $2.5-5$ million, and a small percentage in the category $<1$ million and $5-7.5$ million; and (3) graduates working in Other Institutions almost half of them in categories of 7.5 to 10 million, and a small percentage in categories: 2.5 - 5 million, 5 - 7.5 million and > 10 milion.

Third, the method chosen by most graduates to find a job today is to build a network since college, whether it is a graduate who works in Higher Education, vocational schools, or other institutions. This can be seen in Table 3 .

T ABLE III METHODS OF FINDING GRADUATE EMPLOYMENT

\begin{tabular}{|c|c|c|c|}
\hline \multirow[b]{2}{*}{ Categories } & \multicolumn{3}{|c|}{ Number / Percentage by Workplace Graduates } \\
\hline & College & $\begin{array}{c}\text { Vocational } \\
\text { School }\end{array}$ & $\begin{array}{c}\text { Other } \\
\text { Institutions }\end{array}$ \\
\hline $\begin{array}{l}\text { Build a net work } \\
\text { since college }\end{array}$ & 15 people $(48 \%)$ & 2 people $(20 \%)$ & $\begin{array}{c}1 \text { person } \\
(11 \%)\end{array}$ \\
\hline $\begin{array}{l}\text { Build your own } \\
\text { business }\end{array}$ & 2 people $(6 \%)$ & 2 people $(20 \%)$ & - \\
\hline $\begin{array}{l}\text { Contacted by } \\
\text { students / } \\
\text { graduates }\end{array}$ & 1 people $(3 \%)$ & - & - \\
\hline $\begin{array}{l}\text { Contacted by } \\
\text { company/ } \\
\text { institution }\end{array}$ & 4 people $(13 \%)$ & - & $\begin{array}{l}1 \text { person } \\
(11 \%)\end{array}$ \\
\hline $\begin{array}{l}\text { Information from } \\
\text { Graduate }\end{array}$ & 4 people $(13 \%)$ & - & - \\
\hline $\begin{array}{l}\text { Work placement / } \\
\text { internship }\end{array}$ & 3 people $(10 \%)$ & - & $\begin{array}{c}1 \text { person } \\
(11 \%)\end{array}$ \\
\hline $\begin{array}{l}\text { Relation (eg: } \\
\text { parent, relative, } \\
\text { friend, etc.) }\end{array}$ & 5 people $(16 \%)$ & 1 person $(10 \%)$ & $\begin{array}{c}1 \text { person } \\
(11 \%)\end{array}$ \\
\hline $\begin{array}{l}\text { Ads in newspapers } \\
\text { / magazines \& } \\
\text { brochures }\end{array}$ & 1 person $(3 \%)$ & - & - \\
\hline $\begin{array}{l}\text { Internet/online } \\
\text { advertising }\end{array}$ & 6 people $(19 \%)$ & 2 people $(20 \%)$ & - \\
\hline $\begin{array}{l}\text { Apply without } \\
\text { knowing the } \\
\text { vacancy }\end{array}$ & 4 people $(13 \%)$ & 1 person $(10 \%)$ & - \\
\hline Other jobs & 3 people $(10 \%)$ & 1 person $(10 \%)$ & - \\
\hline
\end{tabular}

(Source: Descriptive analy sis results with Microsoft Excel 2010)
Table 3 shows that: (1) graduates who work in universities are almost half in the category of network building since college, and a small percentage in 10 other categories; (2) graduates who work in SMK a small part in the category: build networks since college, build their own business, and internet / online advertising; and (3) graduates working in Other Institutions in small categories: building networks since college, contacted by companies / agencies, work / apprenticeship, and relationships (eg parents, relatives, friends, etc.).

Fourth, the waiting period of most graduates since getting a Master's degree is less than a month, whether graduates who work in Higher Education, Vocational School, or Other Institutions. This can be seen in the following table.

TABLE IV GRADUATE PERIOD OF WORK

\begin{tabular}{|l|c|c|c|}
\hline \multirow{2}{*}{ Categories } & \multicolumn{3}{|c|}{ Number / Percentage by Workplace Graduates } \\
\cline { 2 - 4 } & College & $\begin{array}{c}\text { Vocational } \\
\text { School }\end{array}$ & Other Institutions \\
\hline$<1$ month & 15 people (48\%) & 4 people (40\%) & 4 people (40\%) \\
\hline 1 month & 3 people (10\%) & 2 people (20\%) & 2 people (20\%) \\
\hline 2 months & - & - & - \\
\hline 3 months & 4 people (13\%) & 1 person (10\%) & 1 person (10\%) \\
\hline 4 months & - & 1 person(10\%) & 1 person (10\%) \\
\hline 5 months & 1 person (3\%) & - & - \\
\hline 6 months & 1 person (3\%) & - & - \\
\hline$>6$ months & 3 people (10\%) & - & - \\
\hline \multicolumn{4}{|c}{ (Source: Descriptive analysis results with Microsoft Excel 2010) }
\end{tabular}

Table 4 shows that: (1) graduates working in universities are almost half in the $<1$ month category, and a small percentage in the categories: 1 month, 3 months, 5 months, 6 months, and > 6 months; (2) graduates working in vocational schools are almost half in the $<1$ month category, and a small percentage in the categories: 1 month, 3 months, and 4 months; and (3) graduates working in Other Institutions almost half of the <1 month category, and a small percentage in the categories: 1 month, 3 and 4 months. Some graduates have been working before taking the lessons in S2 Program of PKJ UM, so they do not need the method and waiting period to find work at this time. The graduates who have been working are: (1) graduates working in Universities as many as 4 people $(13 \%$, (2) graduates who work in MSC as many as 3 people (30\%), and (3) graduates working in other institutions as many as 5 people $(56 \%)$.

\section{B. Satisfaction of Learning Service Graduate S2 Vocational Education State University of Malang}

The data presented in the Learning Service Satisfaction Variables are described by reviewing the 5 subvariables: (1) Tangibles (Direct evidence), (2) Reliability, (3) Responsiveness, (4) Assurance ), and (5) Empathy. Description of graduate data presented by dividing the respondents into three categories according to the place of respondent's current work (respondents working in Higher Education, SMK, and Other Institutions). The satisfaction of learning service of graduates who work in Higher Education is satisfactory. This can be seen from the total results of the analysis of the subvariables of service learning satisfaction variables in Table 
5, which indicates that the total satisfaction of learning services is generally considered satisfactory category.

TABLE V ANALYSIS RESULTS OF VARIABLE SATISFACTION LEARNING SERVICE GRADUATES WHO WORK IN UNIVERSITIES

\begin{tabular}{|l|l|l|l|l|l|}
\hline Variabel & Subvariabel & Mean & Categori & $\begin{array}{l}\text { \% } \\
\text { Categori }\end{array}$ & Criteria \\
\hline \multirow{3}{*}{$\begin{array}{l}\text { Satisfaction } \\
\text { of Learning } \\
\text { Services }\end{array}$} & Tangibles & 12.52 & Satisfactory & 78,23 & $\begin{array}{l}\text { In } \\
\text { general }\end{array}$ \\
\cline { 2 - 6 } & Reliability & 11,97 & Satisfactory & 74,80 & Mostly \\
\cline { 2 - 6 } & Responsiveness & 9,19 & Satisfactory & 76,61 & $\begin{array}{l}\text { In } \\
\text { general }\end{array}$ \\
\cline { 2 - 6 } & Assurance & 18,71 & Satisfactory & 77,96 & $\begin{array}{l}\text { In } \\
\text { general }\end{array}$ \\
\cline { 2 - 6 } & Empathy & 9,39 & Satisfactory & 78,23 & $\begin{array}{l}\text { In } \\
\text { general }\end{array}$ \\
\hline \multirow{2}{*}{ Total } & 61,77 & \multicolumn{2}{|c|}{ Satisfactory } & 77,23 & $\begin{array}{l}\text { In } \\
\text { general }\end{array}$ \\
\hline
\end{tabular}

Table 5 shows that: (1) Generally (78.23\%) Tangibles are categorized as Satisfactory with mean 12.52; (2) Most $(74.80 \%)$ Reliability is satisfactory category with mean of 11.97; (3) Generally (76.61\%) Responsiveness is Satisfactory category with mean 9,19; (4) In general (77.96\%) Assurance is satisfied with the category of 18.71; and (5) Generally (78.23\%) Empathy is categorized as Satisfactory with mean 9.39. Total of Service Learning Satisfaction shows in general (77.23\%) including satisfactory category with mean of 61.77. The satisfaction of graduate learning services working in SMK is satisfactory. This can be seen from the total results of the analysis of the subvariables of service learning satisfaction variables in Table 6, which shows that the total satisfaction of learning services in general is satisfactory.

TABEL VI ANALYSIS RESULTS OF VARIABLE SATISFACTION LEARNING SERVICE GRADUATES WHO WORK IN VOCATIONAL HIGH SCHOOL

\begin{tabular}{|c|c|c|c|c|c|}
\hline Variabel & Subvariabel & Mean & Categori & $\begin{array}{l}\% \\
\text { Categori }\end{array}$ & Criteria \\
\hline \multirow{5}{*}{$\begin{array}{l}\text { Satisfaction } \\
\text { of Learning } \\
\text { Services }\end{array}$} & Tangibles & 12.3 & Satisfactory & 76,87 & $\begin{array}{l}\text { In } \\
\text { general }\end{array}$ \\
\hline & Reliability & 11,6 & Satisfactory & 72,5 & Mostly \\
\hline & Responsiveness & 9,4 & Satisfactory & 78,33 & $\begin{array}{l}\text { In } \\
\text { general }\end{array}$ \\
\hline & Assurance & 16,4 & Satisfactory & 78,09 & $\begin{array}{l}\text { In } \\
\text { general }\end{array}$ \\
\hline & Empathy & 9 & Satisfactory & 81,82 & $\begin{array}{l}\text { In } \\
\text { general }\end{array}$ \\
\hline \multicolumn{2}{|l|}{ Total } & 60,2 & Satisfactory & 81,35 & $\begin{array}{l}\text { In } \\
\text { general }\end{array}$ \\
\hline
\end{tabular}

(Source: Descriptive analy sis results with IBM SPSS Statistics 20)

Table 6 shows that: (1) Generally (76.87\%) Tangibles are categorized as Satisfactory with mean 12.3 ; (2) Most $(72.5 \%)$ Reliability belongs to the Satisfactory category with mean of 11.6; (3) Generally (78.33\%) Responsiveness is satisfactory with mean 9.4; (4) Generally (78.09\%) Assurance is satisfactory with mean 16,4; and (5) Generally (81.82\%) Empathy is categorized as Satisfactory with mean 9. Total of Service Learning Satisfaction indicates in general $(81.35 \%)$ including satisfactory category withmean 60.2 .
The satisfaction of graduate learning services working in Other Institutions is satisfactory. This can be seen from the total results of the analysis of the subvariables of learning service satisfaction variables in Table 7 , which indicates that the total satisfaction of learning services in general including satisfactory categories.

TABEL VII ANALYSIS RESUlTS OF VARIABLE SATISFACTION LEARNING SERVICE GRADUATES WHO WORK IN OTHER INSTITUTIONS

\begin{tabular}{|l|l|l|l|l|l|}
\hline Variabel & Subvariabel & Mean & Categori & $\begin{array}{l}\text { \% } \\
\text { Categori }\end{array}$ & Criteria \\
\hline \multirow{4}{*}{$\begin{array}{l}\text { Satisfaction } \\
\text { of Learning }\end{array}$} & Tangibles & 12.33 & Satisfactory & 77,08 & $\begin{array}{l}\text { In } \\
\text { general }\end{array}$ \\
\cline { 2 - 6 } & Reliability & 11,44 & Satisfactory & 71,53 & Mostly \\
\cline { 2 - 6 } & Responsiveness & 9,11 & Satisfactory & 75,93 & Mostly \\
\cline { 2 - 6 } & Assurance & 18 & Satisfactory & 85,71 & $\begin{array}{l}\text { In } \\
\text { general }\end{array}$ \\
\cline { 2 - 6 } & Empathy & 9,33 & Satisfactory & 84,85 & $\begin{array}{l}\text { In } \\
\text { general }\end{array}$ \\
\hline \multirow{2}{*}{ Total } & 60,22 & Satisfactory & 81,38 & $\begin{array}{l}\text { In } \\
\text { general }\end{array}$ \\
\hline
\end{tabular}

(Source: Descriptive analy sis results with IBM SPSS Statistics 20)

Table 7 shows that: (1) Generally (77.08\%) Tangibles are categorized as Satisfactory with mean 12.33; (2) Most (71.53\%) Reliability is satisfactory category with mean of 11.44; (3) Most $(75.93 \%)$ Responsiveness is Satisfactory category with mean 9.11 ; (4) in general $(85.71 \%)$ Assurance is satisfied with the category of 18; and (5) Generally $(84.85 \%)$ Empathy is categorized as Satisfactory with mean 9.33. Total of Service Learning Satisfaction shows in general $(81.38 \%)$ including satisfactory category with mean of 60.22 .

\section{DISCUSSION}

A. Profile of Master Degree Graduates of Vocational Education State University of Malang

The graduate profile involves the identity of the respondent, main activities after the graduation, monthly main job income, job search methods, and the work waiting period shows that the master degree's graduate of PKJ UM who works in a college, Vocational School, or other Institution has the absorption ability, process, and a good position in the work's world. This can be seen from the main activities of graduates after the graduation which indicates a good absorption in the work's world where most of the graduates choose to work as their main activity after graduation.

The monthly income of graduates from the main job also shows that the graduates have a good position in the world of work. This can be seen from the monthly income of the graduates which are above of UMK Malang Raya in 2017. As has been socialized by the Transmigration and Manpower Office of Malang related to the UMK Malang Raya in 2017 at the Hall Room of Malang City on December 7, 2016, that: Malang City has monthly income of graduates as much as Rp. 2,272,167.50; Malang Regency has monthly income of graduates as much as Rp 2,368,510.00; and Kota Batu has monthly income of graduates as much as Rp 2,193,145.00; (Public Information Field, 2016). Analysis of the research results shows that graduates who working in the university and vocational schools almost half of them have the income 
between 2.5 to 5 million per month. While the graduate who works in other institutions almost half of them have the income between 7.5 to 10 million per month.

The method and the work waiting period of graduates to find the work also show a good process in the world of work now. This can be seen from most of graduates now who have a work waiting period of less than 1 month to find a job. Even some of graduates have been working before taking the lessons in Master Degree's Program in PKJ UM. Most of the graduates also choose to build the network since they are still in the college as a method of finding work.

\section{B. Satisfaction of Learning Service Graduate S2 Vocational Education State University of Malang}

The results revealed that the satisfaction of learning service from Tangibles aspect, Reliability aspect, Responsiveness aspect, Assurance aspect, and Empathy aspect for Master Degree's graduate of Vocational Education in State University of Malang (PKJ UM) whether they work in Universities, Vocational Schools, or other institutions, generally, included into the satisfactory category. This can be described as follows.

Satisfaction of learning service is something to be considered in order to prepare the quality of Human Resources (HR). Today, the improving of education services quality has become the main program of government[14]. Therefore, it is necess ary to improve the quality of service in vocational higher education which in this case is the Master Degree's Program of PKJ UM. Rasli argues that to achieve the dual purpose of satisfaction and loyalty, the quality of services in the education sector especially in universities needs to be evaluated from an internal (customer) and external (service provider) perspective [35]. The quality of educational services, then should be oriented on what is perceived by the recipient of services to the services provided by the service provider, that is the college [14].

Satisfaction according to Philip Kotler is the feeling of pleasure or disappointment of someone who emerged after comparing the perception or the impression of the performance or the outcome of a product and its hopes [20]. Then the satisfaction of learning service is the level of satisfaction on the service to the learning that has been held by an institution. In other words, the level of quality of education services can be based on the level of satisfaction of graduate services on the learning that has been held. By knowing the level of learning service satisfaction, it will also be known that the next level of service quality can be used to improve the quality of education services, so that will create the quality of education. Because, conceptually, quality of education can be indicated as a capable education service of producing educational output in accordance with the demands of society or professional work's world [14].

The satisfaction of learning services can be known from the quality of service, because the quality of service refers to the quality of service offer expected and felt, where the satisfaction of learning service is determined from customer satisfaction [5]. Service quality can be measured through the service quality model (SERVQUAL). The SERVQUAL model is proposed by Parasuraman which initially identifies the ten basic dimensions that create several criteria that can be used in assessing service quality [29]. Then in the next study, Parasuraman refined these 10 dimensions by testing the final item content that formed each of five straight dimensions: tangibles, reliability, responsiveness, assurance, and empathy [30].

SERVQUAL model is one of scale that most used by many researcher in most of the research to measure the perceived quality of service [18]. Some research show that discrepancy and relativeness of quality service from five quality service dimension is spread evenly to all respondents, although with some specific differences [13]. Other research also shows that satisfy level is equal with their willingness to give big effort to their research [15]. Malik and Kayatsha add, through their research, we know that education quality is an important national development predictor which must to be considered when processing strategy to pull and hold students who want get high education [21].

Learning service satisfaction can be observed from tangibles, reliability, responsiveness, assurance, and empathy aspect. Analysis research result shows that PKJ UM S2 graduated students who work in University, Vocational High School and other institutions is in satisfying category in each aspects and total of all as pects. The category percentage in each aspects shows 'average' criteria, except in Reliability aspect. In reliability aspect, the category percentage shows 'most of' criteria for graduated students who work in University, Vocational High School and other institutions. But for the category percentage total from all aspects show 'average' criteria for graduated students who work in University, Vocational High School and other institutions.

There is no significant problem related to the Learning Service Satisfaction which is all categories in the aspects and the total show satisfying category to all graduated students who work in this three kinds institutions. But there is aspect that must to be put in big attention on the criteria of category percentage per-aspect learning service satisfaction variable, which is reliability aspect. All of the category percentage criteria on reliability aspect show 'most of " for the graduated students who work in University, Vocational High School and other institutions. It is shows that there is equality in decreasing category percentage to all graduated students related to reliability aspect, where other aspects show 'average' category percentage although total of category percentage from all aspects show 'average'.

Reliability is ability in giving the promised service with accuracy and carefulness [01]. Reliability aspect in this research consist of 2 (two) dimensions, i.e. Lectures Service by Lecturer with 2 descriptor: (1) Lectures Planning, and (2) implementation and advanced, and Student Administration Service with the descriptor is ability of administrative staff.

Interview data show that aspect of reliability especially on 'implementation and advanced' descriptor from Lectures Service by lecturer become the spotlight of the graduates to expect its development. This can be reviewed from interview data showing that decreasing category of percentage related to reliability aspect caused by the number of lecturers who teaches courses in the UM PKJ S2 program still holding master 
degree (S2), and very few lecturers who hold Doctor (S3) or Professor. Expressed by the recent graduates of UM PKJ S2 program, that when they were learning in the UM PKJ S2 program, there are still some lecturers with master's degree (S2) who teaches subjects in the field of concentration, although it has been reduced from years. As for the course in the field of education has been teaches by the lecturers who held Doctor and Professor. This is what causes differences in category percentage on the aspect of reliability. But apart from that, there is no significant problem related to service learning satisfaction in which all categories on the aspects and the totals show satisfactory categories on all graduates working in all three types of institutions. In the end, all dimensions (5 dimensions) of service quality have an important position in the education sector and play an important role in the satisfaction of learners so worthy to be examined. Whenever there are deficiencies in the dimensions of service quality will affect learners' satis faction [18].

Based on the above description it is known that the satisfaction of learning service UM PKJ S2 program graduates both working in University, Vocational High School and other institutions are generally satisfied with their learning in UM PKJ S2 program both in terms of tangibles, reliability, responsiveness, as surance and empathy aspect.

Satisfaction of learning service in this study measures satisfaction of learning service UM PKJ S2 graduates based on the profes sion of graduates categorized by researcher into three categories (graduates who work in University, Vocational High School and other institutions). The satisfaction of the learning service in this study is also explained in more detail through five aspects of the SERVQUAL model. This is slightly different from previous research i.e. tracer study University of Indonesia (UI) in 2010 which was investigated by the head of UI Career Development Center (CDC-UI) which measures the satisfaction of learning services based on graduate faculty and the elaboration of satisfaction with learning in general[11].

The study results of the learning service satisfaction in this study are expected to be more complement terms of representation and accuracy related to what should be investigated to determine the satisfaction of learning services through Tracer study. By knowing the level of service satisfaction of graduates on the learning that has been held, then UM PKJ S2 program can improve the quality of its study program. Because the tracer study used is a feedback that can be used to improve the quality of study program, a complete data collection of graduates of a study program is necessary to suit the demands of the needs and the dynamics of current and future society [34].

Information obtained through this tracer study can be used to measure performance courses through graduates that can fulfill demands of the times and is a reference for the development and implementation of the quality assurance system of education [49]. So it can be as one of the foundations in making academic policy in the future by the institution of education providers. The success of graduates in entering the world of work is one indicator of learning outcomes and relevance of learning outcomes for the society [36]. The success of graduates in entering the world of work and performing their roles in various fields of work they live in professionally according to interest and ability is one indicator of learning outcomes and relevance of learning outcomes for the society as well as an indicator of the success of the education process [43].

\section{CONCLUSIONS AND SUGGESTIONS}

Based on research results and discussion can be summarized as follows. First, service learning satisfaction in terms of Tangibles, Reliability, Responsiveness, Assurance, and Empathy, S2 graduate Vocational Education State University of Malang is in the category of satisfactory. Second, absorption power, process, and position in the world of work viewed from the main activities after graduation, monthly income, waiting period, and job search methods, S2 graduate of PKJ UM is in the good category.

Based on the results of research and discussion can be given suggestions as follows. First, universities are advised to run the tracer study program in order to know the absorption, process, and position of graduates in the world of work so as to prepare graduates in accordance with the competencies required in the world of work and can assist the government in order to map and align the needs of the world of work with competencies gained from universities. Second, the director and the head of the study program are advised to pay more attention to the aspects of the learning service in terms of both academic and non-academic for the improvement and quality assurance of higher education institutions. Third, the Administrative Staff is advised to better understand the characteristics of students related to the interests and difficulties of the students so as to create a more conducive and intelligent learning atmosphere and add insight in the consideration to evaluate the development of Study Program services. Fourth, S2 graduate of PKJ UM is expected to be more participate (give critical input / build description and inspiration related to reality encountered in the world of work as well) if found again in the future things related to the development of educational institutions. Fifth, the researcher can then conduct research in the wider scope of graduates or larger population (in terms of domicile or graduates) to get more comprehensive conclusions. As well as improving the accuracy of research instruments (use of other variables and different perspectives) and data accuracy (related graduates are scattered in various regions both inside and outside the country)."

\section{ACKNOWLEDGMENT}

Thank you to Prof. Dr. Amat Mukhadis, M.Pd as mentor I and Mr. Apif Miftahul Hajji, M.T, M.Sc, Ph.D. as mentor II and family and all parties who provide assistance and support in completion of this research.

\section{REFERENCES}

[1] Ahmed, I., Nawaz, M.M., Ahmad, Z., Ahmad, Z., Shaukat, M.Z., \& Usman, A.Rehman, W., Ahmed, N. (2010). Does Service Quality Affect Students' Performance? Evidence from Institutes of Higher Learning, African Journal of Business Management. 4(12): 2527-2533. 
[2] Amin, M.M. (2011). Pengembangan Mobile Application Tracer Study (StudiKasus: IBI Darmajaya). Jurnal Informatika, 11 (1), 12-22.

[3] Arikunto, S. (2006).Prosedur Penelitian Suatu Pendekatan Praktek. Jakarta: Rineka Cipta.

[4] Arikunto, S. (2010). Prosedur Penelitian Suatu Pendekatan Praktik (Revised Edition). Jakarta : PT Rineka Cipta.

[5] Astuti, H.J. (2012). Analisis Kepuasan Konsumen: SERVQUAL Model dan Important Performance Analysis Model. Retrieved from $\mathrm{http}: / /$ download.portalgaruda.org/article.php?article $=9606 \& \mathrm{val}=621 \& \mathrm{titl}$ $\mathrm{e}=$ ANALISIS $\% 20$ KEPUASAN $\% 20$ KONSUMEN $\% 20$ (SERVQUAL $\% 2$ 0Model\%20dan\%20Important\%20Performance\%20Analy sis\%20Model)

[6] Bidang Informasi Publik.(2016). Upah Minimum Kota Malang 2017 Disosialisasikan. Retrieved from http://malangkota.go.id/2016/12/08/ upah-minimum-kota-malang-2017-disosialisasikan/.

[7] Creswell, J.W. (2007). Qualitative Inquiry and Research Design. Choosing Among Five Approaches (2nd edition). London: Sage.

[8] Dib, H., \& Alnazer, M. (2013). The Impact of Service Quality on Student Satisfaction and Behavioral Consequences in Higher Education Services. International Journal of Economy, Management and Social Sciences, 2 (1): 285-290.

[9] Djatmiko, I W. (2015). Inkonsistensi Penyelenggaraan Pendidikan Sekolah, posted by Edi Mulyadin. Retrieved from http://staff.uny.ac.id/sites/default/files/ Inkonsistensi\%20SMA\%20 SMK-rev.pdf..

[10] Faruk, A. (2015). Analisis survival parametrik pada data tracer study Universitas Sriwijaya. Jurnal Matematika, 5 (2), 68-78. Retrieved from http://ojs.unud.ac.id/ index.php/jmat/article/view/21594/14286.

[11] Fikawati, S. (2012). Hasil Tracer Study 2010: Tracer Study UI 2010, posted by Rahmadi. Retrieved from http://cdc.ui.ac.id/index.php? option $=$ com_content $\&$ task=view\&id=777\&Itemid=121

[12] Fitrihana, N., Ekawatiningsih, P., Chayati, I., Asiatun, K. \& Tritanti, A. (2014). Kajian Tracer Study Lulusan Jurusan PTBB FT UNY Tahun 2012. Jurnal Pendidikan Teknologi dan Kejuruan, 22 (1), 55-65.

[13] Hanaysha, J.R., Abdullah, H.H., \& Warokka, A. (2011). Service Quality and Students's Satisfaction at Higher Learning Institutions: The Competing Dimensions of Malaysian Universities's Competitiveness, Journal of Southeast Asian Research, 4(1): 1-10.

[14] Jaedun, A. \& Ishartiwi. (2013). Survei Tingkat Kepuasan Konsumen Terhadap KualitasPelayanan Publik Bidang Pendidikan Di Daerah IstimewaYogyakarta. Retrieved from http://staff.uny.ac.id/sites/default/ files/lain-lain/drs-amat-jaedun-mpd/Kepuasan \%20Lay anan \%20 Pendidikan.pdf .

[15] Khan, M.M., Ahmed, I., \& Nawaz, M.M. (2011). Student's Perspective of Service Quality in Higher Learning Institutions: An Evidence Based Approach. International Journal of Business and Social Science, 2 (11): 159-164.

[16] Khoir, M. (2012). Hasil Belajar dan Pembelajaran. Retrieved from https://mazidatulkhoir.wordpress.com/2012/10/07/hasil-belajar-danpembelajaran/.

[17] Komariah, K. (2010). Memimpikan SMK di Masa Depan. Prosiding dari Seminar Nasional Pendidikan Vokasional: Prospek Pengembangan Pendidikan Vokasional dalam Era Globalisasi, Culinary Education Study Program, FPT K UPI, Bandung, October 27.

[18] Kundi, G.M., Khan, M.S. \& Qureshi, Q.A. (2014). Impact of Service Quality on Customer Satisfaction in Higher Education Institutions (A Case Study of Gomal University, DIKhan, Khyber Pakhtunkhwa Pakistan). Industrial Engineering Letters, 4 (3): 23-28.

[19] Kurniawan, R.A. (2014). Analisis Kepuasan Instansi Pengguna Lulusan Jurusan Pendidikan IPS Ekonomi FITK IAIN Mataram. Jurnal Pendidikan Ilmu Pengetahuan Sosial Ekonomi, 12 (2): 26-44. Retrieved from http://ejurnal.iainmataram.ac.id/index.php/society/article/ view/644/848), diakses 17 Januari 2017.

[20] Londong, D. (2012). Kepuasan Pelanggan (Customer Satisfaction). Retrieved from http://dedylondong.blogspot.co.id/2012/04/kepuasanpelanggan-customer.html.

[21] Malik, M.E., Danish, R.Q. \& Usman, A. (2010). The Impact of Service Quality on Students' Satisfaction in Higher Education Institutes of Punjab. Journal of Management Research, 2 (2): 1-11.
[22] Mayang, S., Yadi, Y.H. \& Susihono, W. (2013). Evaluasi Tracer Study Untuk Pembelajaran dengan Pendekatan Ergonomi Makro.Jurnal Teknik Industri, 1 (4): 284-288.

[23] Mukhadis, A. (2009). Pengembangan Kemampuan Emulasi melalui Teaching Industries dalam Bidang Teknologi. Jurnal Teknologi dan Kejuruan, 32 (2): 219-236.

[24] Mukhadis, A. (2013a). Evaluasi Program Pembelajaran Bidang Teknologi: Terminologi, Prosedur Pengembangan Program Dan Instrumen. Malang: Bayumedia.

[25] Mukhadis, A. (2013b). Sosok Manusia Indonesia Unggul dan Berkarakter dalam Bidang Teknologi Sebagai Tuntutan Hidup di Era Globalisasi.Jurnal Pendidikan Karakter, 3 (2): 115-136.

[26] Mukhadis, A. (2015). Kiat Menulis Karya Ilmiah: Bentuk, Anatomi, Isi Esensial, dan Contoh Aplikasinya. Malang: Aditya Media Publishing.

[27] Mukhadis, A. (2016). Metode Penelitian Kuantitatif: Bidang Pendidikan dan Contoh Aplikasinya. Malang: Aditya Media Publishing.

[28] Nuroso, H., Khoiri, N., Saptaningrum, E. \& Siswanto, J. (2008). Studi Penelusuran Alumni Jurusan Pendidikan Fisika IKIP PGRI Semarang Untuk Menyempurnakan Kurikulum Berdasarkan Kebutuhan di Lapangan (Pasar Kerja). Jurnal Media Penelitian Pendidikan, 2 (2), 125-140.

[29] Parasuraman, A.,Zeithaml, V.A. \& Berry, L.L. (1985). A Conceptual Model of Service Quality and Its Implications for Future Research.Journal of Marketing, 49 (Fall 1985): 41-50.

[30] Parasuraman, A.,Zeithaml, V.A. \& Berry, L.L. (1988). SERVQUAL: A Multiple-Item Scale for Measuring Consumer Perceptions of Service Quality. Journal of Retailing, 64(1): 12-40.

[31] Pascasarjana UM. (2013). Katalog Pascasarjana Tahun Akademik 2013/2014, Program Studi Pendidikan Kejuruan. Malang: Pascasarjana Universit as Negeri Malang.

[32] Permendiknas No.22. (2006). Standar Isi untuk Satuan Pendidikan Dasar Dan Menengah. Jakarta: Menteri Pendidikan Nasional.

[33] Rahmatullah, M., Mukhadis, A. \& Hajji, A.M. (2016). Keterkaitan Pendidikan Tinggi dengan Dunia Kerja Profesional: Masalah, Faktor Penyebab, dan Solusinya. Prosiding dari Seminar Nasional Pendidikan Kejuruan: Tantangan Pendidikan Kejuruan Abad XXI, Program Studi Pendidikan Kejuruan Program Pascasarjana UM, Malang, 24 September.

[34] Rasiman, Cahyono, A.N., Sulianto, J. \& Nurhadi. (2008). Penelusuran Lulusan Program Studi Pendidikan Matematika Ikip Pgri Semarang Melalui Studi Pelacakan (Tracer Study) Sebagai Umpan Balik Penyempurnaan Kurikulum Tahun 2008. Jurnal Media Penelitian Pendidikan, 2 (2), 162-173. Retrieved from http://ejurnal.upgrismg.ac.id/index.php/mediapenelitianpendidikan/ article/view/280/248).

[35] Rasli, A., Danjuma, I., Yew, L.K. \& Igbal, M.J. (2011). ServiceQuality, Customer Satisfaction in Technology Based Universities. African Journal of Business Management, 5 (15): 6541-6553.

[36] Ristekdikti. (2016). Panduan Hibah Tracer Study. Jakarta: Ristekdikti.

[37] Saillah, I. (2013). Buku Panduan Sistem Pusat Karir. Jakarta: Kemendikbud. Dikti. Direktorat Pembelajaran dan Kemahasiswaan.

[38] Salim, S. (2011). Upaya Peningkatan Kompetensi Profesional Guru Sekolah Kejuruan. Jurnal Ilmu Pendidikan Pedagogika. 2 (1), 18-24. Retrieved from http://ejurnal.fip.ung.ac.id/index.php/PDG/article/ view/135/130.

[39] Setiawati, L. (2010). Penelusuran Lulusan Program Studi Pendidikan Bahasa dan Sastra Indonesia Fakultas Keguruan dan Ilmu Pendidikan Universit as Terbuka. Jurnal Pendidikan Terbuka dan Jarak Jauh, 11 (2),75-83.Retrieved from http://jurnal.ut.ac.id/JPTJJ/article/view/ $293 / 293$

[40] Schomburg, H. (2003). Handbookfor Graduate Tracer Studies. Kassel: Centre for Research Higher Education and Work, University of Kassel

[41] Sofyan, H., Pardjono, Djatmiko, I.W. \& Sudira, P. (2015). Paradigma Baru Pendidikan Vokasi. Retrieved from http://staff.uny.ac.id/ sites/default/files/pengabdian/prof-dr-herminarto-sofyan-mpd/.

[42] Sugiyono. (2011). Metode Penelitian Kuantitatif, Kualitatif, dan R\&D. Bandung: Penerbit Alfabeta. 
[43] Sukardi, T. (2011). Studi Penelusuran Lulusan S1 Kependidikan Fakultas Teknik Universitas Negeri Yogyakarta. Jurnal Pendidikan Teknologi dan Kejuruan, 20 (2), 196-202. Retrieved from http://journal.uny.ac.id/index.php/ jptk/article/view/3318/2790.

[44] Suryadi, Ace. (2010). Permasalahan dan Alternatif Kebijakan Peningkatan Relevansi Pendidikan. Relevance Study of Education, a Cooperation between UPI and Balitbang Kemendiknas delivered on International Seminar at Outside School Education, PLS-SPS UPI, Bandung, November 29.

[45] Tamtama, A., Asis, P.H., Hartati, Nuryadi, A.M., Maheng, M.D., Syahriani, R., Febrianti \& Jumiatin. (2013). Tracer Study Alumni Tahun 2013 Universitas Muhammadiyah Kendari. Retrieved from https://www.academia.edu/21515535/Tracer_Study_Alumni_Tahun_20 13_Universitas_Muhammadiyah_Kendari_Penulis.

[46] Taslim, Soni. (2014). Problematika Pendidikan Kejuruan dan Kompleksnya Masalah Pendidikan Di Indonesia.Ternyata Hanya Terletak Pada Satu Kata: Komitmen. Retrieved from http://sontaslim.blogspot.com/2014/12/problematika-pendidikankejuruan-dan_14.html.

[47] Republic of Indonesia Law No. 20/2003 about National Education System. Jakarta: DPR Republik Indonesia.

[48] Wuryandini, E. (2014). Analisis Permasalahan dan Kebutuhan Pengembangan Keprofesian Berkelanjutan Guru SMK Bidang Keahlian Bisnis dan Manajemen Pascasertifikasi di Kota Semarang. Jurnal Manajemen Pendidikan, 9 (2), 108-119. Retrieved from http://journals.ums.ac.id/index.php/ jmp/article/download/1692/1194.

[49] Yani, D.E., Pertiwi, P.R., Fadila, I., Puspitasari, K.A. \& Huda, N. (2012). Tracer study pada program studi S1 Agribisnis FMIPAUniversitas Terbuka. Jurnal Pendidikan Terbuka dan Jarak Jauh, 13 (2), 94-105. Retrieved from http://jurnal.ut.ac.id/JPTJJ/ article/view/248/250 